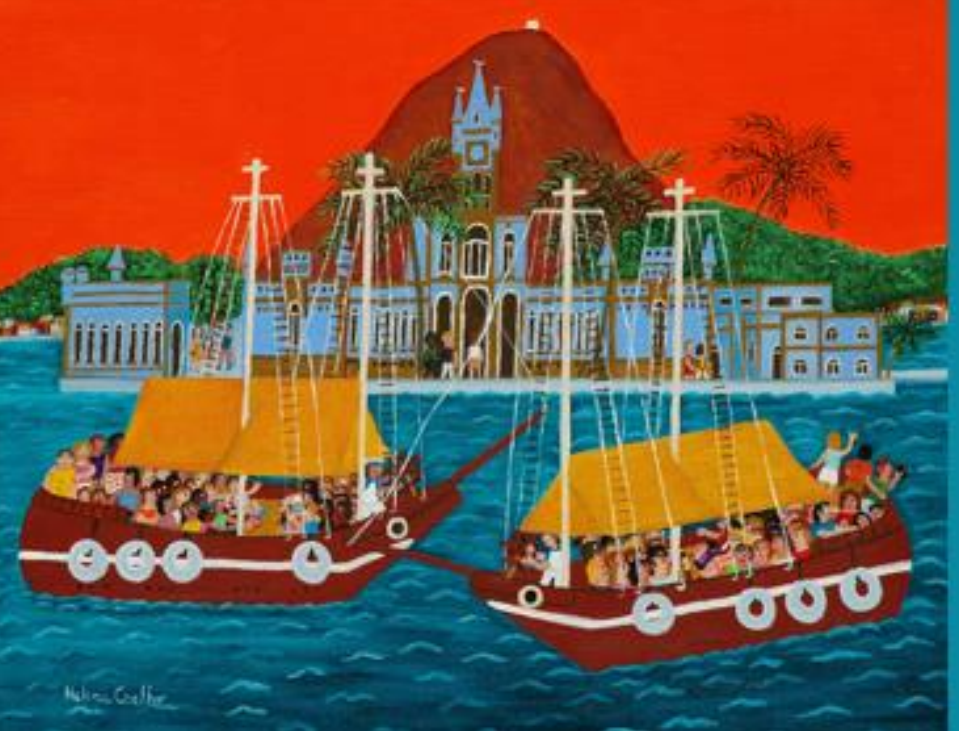

\title{
FILHO SEM PAI, PAI SEM FILHO: A ESCRITA ÍNTIMA DO LUTO
}

\section{SON WITHOUT FATHER, FATHER WITHOUT SON: THE INTIMATE WRITING OF GRIEF}

\author{
Lara Luiza Oliveira AMARAL \\ Universidade Estadual de Campinas, Brasil
}

\author{
Eduardo Bertoli LUDWIG \\ Universidade Estadual do Paraná, Brasil
}

RESUMO | INDEXAÇÃO | TEXTO | REFERÊNCIAS | CITAR ESTE ARTIGO | OS AUTORES RECEBIDO EM 28/10/2020 • APROVADO EM 22/02/2021

DOI: https://doi.org/10.47295/mgren.v10i1.2940

\section{Resumo}

Um filho perde o pai. Um pai perde uma filha. São esses os títulos e enredos das duas narrativas selecionadas para a análise a seguir. 0 primeiro volume da saga Minha Luta, de Karl Ove Knausgård, se intitula A morte do pai (2009). 0 romance de estreia do brasileiro Tiago Ferro, $O$ pai da menina morta (2018). A década de diferença não altera o foco dos romances: a morte, o luto, a escrita. A partir de uma leitura comparativa entre as duas obras, objetivamos analisar a representação do luto (e do enlutado) na literatura autoficcional contemporânea. Para tanto, nos pautaremos em teóricos, tais como Lejeune (1975), Arfuch (2002), Freud (1917), entre outros. 
A son loses his father. A father loses his daughter. These are the titles and plots of the two narratives selected for the following analysis. The first volume of the series My Struggle, by Karl Ove Knausgård, is entitled $A$ death in the family (2009). The debut novel of the brazilian Tiago Ferro, $O$ pai da menina morta (2018). The decade of difference doesn't change the focus of the novels: death, mourning, writing. From a comparative reading between both of them, we aim to analyze the representation of mourning (and the mourner) in contemporary autofiction literature. Therefore, we will be guided by theorists, such as Lejeune (1975), Arfuch (2002), Freud (1917), among others.

Entradas para indexação

Palavras-chave: Luto. Literatura contemporânea. Autoficção.

Keywords: Mourning. Contemporary literature. Autofiction.

\section{Texto integral}

Não quero falar disso por medo de fazer literatura - ou sem estar certo de que não o será -, embora, de fato, a literatura se origine dessas verdades.

(O diário do luto, de Roland Barthes)

\section{$1 \quad$ O Pai e o Filho}

"Para o coração a vida é simples: ele bate enquanto puder. Então para.", essas são as palavras que abrem o primeiro volume da trilogia de Karl Ove Knausgård, A morte do pai (2009). Estas também são as palavras que abrem o romance $O$ pai da menina morta (2018), de Tiago Ferro, em forma de epígrafe. Um brasileiro e um norueguês, no intervalo de uma década, (d)escrevem seu luto. Knausgård perde o pai, Ferro perde a filha - na narrativa e na vida. A perda atua como força motriz para a escrita, sendo o tema central dos romances, do título ao conteúdo.

Em A morte do pai $^{1}$, Knausgård se apresenta como pai, filho, marido e escritor. As dificuldades do autor em escrever enquanto lida com tarefas domésticas, as visitas ao seu passado e sua conturbada relação com o seu pai, são os tópicos que estruturam sua narrativa. Em um jogo entre passado e presente, mescla cenas da infância com a situação atual: lidar com a morte do pai.

0 romance $O$ pai da menina morta $^{2}$, relata o processo de luto do protagonista após perder sua filha de forma inesperada, uma complicação de saúde pouco comum em uma criança aos oito anos de idade. 0 enredo foca na tentativa de representação e consequências do luto do Pai: o término do casamento, novos relacionamentos, a escrita de um livro.

\footnotetext{
${ }^{1}$ Karl Ove Knausgård tornou-se um autor de destaque após relatar, de certa forma, sua vida em uma série de livros denominada Min kamp (Minha Luta) (2009-2011). Composta por seis volumes, cada livro retrata a passagem de fatos e reflexões cotidianas do autor.

2 Vencedor do prêmio Jabuti de romance em 2019.
} 
Para além da presença da figura da morte como fato comum entre as duas obras, ressaltamos o caráter íntimo de tais narrativas. Tão íntimo que, muitas vezes, confunde realidade e ficção. Ambas as obras refletem essa "escrita íntima do luto", em que a perda é "real" e a escrita joga entre verdade e criação artística. Para discutir a relação autobiográfica nos romances selecionados, nos pautaremos, inicialmente, em O pacto autobiográfico (1975), de Philippe Lejeune. De acordo com o teórico, a autobiografia se define como: "narrativa retrospectiva em prosa que uma pessoa real faz de sua própria existência, quando focaliza sua história individual, em particular a história de sua personalidade" (LEJEUNE, 2014, p. 16). 0 autor ainda ressalta a importância da relação de identidade entre as três instâncias do texto: autor, narrador e personagem. Isso porque, para que o "pacto autobiográfico" se concretize é necessário que todos (narrador-autor-personagem) compartilhem do mesmo nome: "a afirmação, no texto, dessa identidade, remetendo, em última instância, ao nome do autor" (LEJEUNE, 2014, p. 30).

Além disso, Lejeune ressalta que: "A identidade narrador-personagem principal, suposta pela autobiografia, é na maior parte das vezes marcada pelo emprego da primeira pessoa" (LEJEUNE, 2014, p. 18). Tal fato se confirma na narrativa de Knausgård, quando se apresenta: "Hoje é dia 27 de fevereiro de 2008. São 23h43. Eu, Karl Ove Knausgård, nasci em dezembro de 1968, portanto, no instante em que escrevo, tenho trinta e nove anos de idade" (KNAUSGÅRD, 2015, p. 24). A relação com os nomes em Knausgård vai para além da sua apresentação enquanto protagonista. $\mathrm{O}$ autor norueguês foi alvo de polêmicas pelo uso real de nomes de amigos e parentes em suas obras publicadas até então, quase sendo processado por alguns desses ${ }^{3}$.

Sobre a relação polêmica existente em gêneros de teor autobiográfico, a teórica brasileira Leila Perrone-Moisés, em Mutações da literatura do século XXI (2016), ressalta:

A autoficção envolve questões éticas. É impossível narrar a própria vida sem incluir outras pessoas. E se o autor não se importa com a autoexposição, outras pessoas retratadas por ele podem-se sentir mal representadas ou mesmo ofendidas. Em casos extremos, os ofendidos podem recorrer à Justiça. (PERRONE-MOISÉS, 2016, p. 209).

A teórica utiliza como exemplo as repercussões da série de Knausgård para discutir os "limites do eu" na autoficção: "Mesmo sem ter sido processado, ele se sentiu muito mal com relação a seus familiares, e teme até mesmo a reação de seus filhos, quando estes tiverem idade para ler sua obra" (PERRONE-MOISÉS, 2016, p. 219). A autora relaciona o sucesso do norueguês com o fato de ter encontrado uma "voz e um olhar 'na mesma altura' que o dos leitores atuais", ou seja, "que o

\footnotetext{
${ }^{3}$ Em uma entrevista para Le Nouvel Observateur, em 2014, ao ser questionado sobre isso, Knausgård responde: "Se eu soubesse o que iria acontecer, não o teria feito". Disponível em: https://bibliobs.nouvelobs.com/rentree-litteraire-2014/20140919.0BS9702/karl-oveknausgaard-j-ai-cree-un-monstre-que-je-ne-controle-plus.html>.
} 
narrador seja uma pessoa reconhecível, que a vida narrada se pareça com a existência deles, que o texto literário lhes revele como essa outra pessoa age, sente e pensa" (PERRONE-MOISÉS, 2016, p. 218). Em contrapartida, apesar de extremamente íntimo, Perrone-Moisés comenta que o texto apaga particularidades ideológicas ou políticas do autor - fatos que, ironicamente, talvez não causassem tantos "problemas" como aqueles de aspecto mais íntimo e pessoal.

A recusa de Tiago Ferro em aceitar a categoria autoficcional de seu romance pode ter uma relação com as polêmicas de Knausgård. Em uma entrevista ${ }^{4}$, Ferro explica que o livro parte de um princípio não-ficcional, a morte precoce de sua filha. "O início do luto", conforme ele diz, dá-se um ano após o ocorrido: "o livro é muito menos sobre a minha filha ou sobre a morte dela, e muito mais sobre um narrador que não tem nome, que é o pai da menina morta". 0 anonimato, ou a ambiguidade proposital na figura paterna que perdeu uma filha, reitera a ideia de representar o luto em âmbito muito mais plural e menos particular - ainda que parta, de fato, de experiências pessoais reais.

Enquanto Knausgård se apresenta com seu nome completo, data de inscrição e ano de nascimento, o protagonista de Tiago Ferro se apresenta como "0 Pai da Menina Morta":

[cartório]

Nome: O Pai da Menina Morta

Data de nascimento: O Pai da Menina Morta

Estado civil: O Pai da Menina Morta

Sexo: O Pai da Menina Morta

Telefone para contato: O Pai da Menina Morta

Assinatura: O Pai da Menina Morta. (FERRO, 2018, p. 37).

Ao se nomear "O Pai da Menina Morta", sua identidade é apagada e substituída pela marca da perda: "Eu não quero ser O Pai da Menina Morta. Eu sempre serei 0 Pai da Menina Morta" (FERRO, 2018, p. 17). Todos os seus dados pessoais passam a ser uma lembrança constante da morte da filha. Também um elemento a ser ressaltado, voltado à estética da escrita, é o uso de colchetes para iniciar os parágrafos. Antes de escrever o romance, Tiago Ferro manteve um diário. O recurso estético pode ser entendido como uma marca das antigas "entradas", agora elemento constituinte da fragmentação de sua narrativa. A "troca" do gênero diarístico para a ficção também parece indicar a necessidade de distanciamento entre autor e personagem.

Apesar das polêmicas envolvendo a publicação de Knausgård, ou mesmo a recusa da categoria autoficcional por Tiago Ferro, devemos estar cientes do constante jogo literário que envolve as escritas do eu. Ainda que se paute em uma base "real", o enfoque literário se fundamenta muito mais no modo como o escritor representou tais experiências. 0 autor atua nos extremos da ficção e do mundo real, dificultando a categorização entre o que é verdadeiro e o que pertence ao imaginário. Situados no vasto mundo de possibilidades da literatura, torna-se

4 Entrevista para o canal "Litera Tamy", publicada em 2019. Disponível em: https://www.youtube.com/watch?v=CwhqlLv0ZFI. 
difícil, e mesmo desnecessário, validar ou invalidar certos discursos com base na sua "veracidade" ou não. Leonor Arfuch, por exemplo, em O espaço autobiográfico: dilemas da subjetividade contemporânea (2002), parte do conceito de "espaço biográfico" de Lejeune e vai além. Tentando escapar dos "limites do gênero" imposto pelo teórico, Arfuch propõe uma discussão sobre a ideia de "real" e "ficção" em textos de teor biográfico.

Mesmo "baseado em fatos reais", Arfuch frisa que o que realmente importa em tais textos não é tanto a sua "verdade", mas o "modo" como são apresentados e representados - os fatos:

\begin{abstract}
Avançando uma hipótese, não é tanto o "conteúdo" do relato por si mesmo - a coleção de acontecimentos, momentos, atitudes - mas precisamente as estratégias - ficcionais - de autorrepresentação o que importa. Não tanto a "verdade" do ocorrido, mas sua construção narrativa, os modos de (se) nomear no relato, o vaivém da vivência ou da lembrança, o ponto do olhar, o que se deixa na sombra; em última instância, que história (qual delas) alguém conta de si mesmo ou de outro eu. E é essa qualidade autorreflexiva, esse caminho de narração, que será, afinal de contas, significante. (ARFUCH, 2010, p. 73).
\end{abstract}

A partir de tais questionamentos, alcançamos uma nova categoria: a autoficção. Como categorizar uma obra em que o nome do personagem é igual ao nome do autor, mas ao mesmo tempo sela um pacto romanesco (ou seja, ficcional); ou, ao contrário, o nome do autor e o nome do personagem se diferem, mas temos um pacto autobiográfico (fatos "pessoais")? Dessas questões, das "lacunas" de Lejeune, Serge Doubrovsky fez surgir o termo "autoficção". Em O último eu (2010), Doubrovsky fala sobre a recusa do termo como um novo "gênero" e suas principais características. De acordo com a definição que deu ao dicionário Robert Culturel, autoficção seria uma "ficção, de fatos e acontecimentos estritamente reais" (DOUBROVSKY, 2014, p. 120).

Um dos pontos que mais nos interessa da autoficção é a consideração de Doubrovsky quanto ao modo de representação de uma vida, das dificuldades e desvios autobiográficos: "Os tempos mudaram. Não se escreve mais romances da mesma forma que nos séculos XVIII ou XIX. Há, entretanto, uma continuidade nessa descontinuidade, pois, autobiografia ou autoficção, a narrativa de si é sempre modelagem, roteirização romanesca da própria vida" (DOUBROVSKY, 2014, p. 124). Indo ao encontro do que propunha Arfuch, Doubrovsky ressalta a impossibilidade de representação conclusiva e exata da experiência.

Quando a experiência em que se pautam para escrever fatos pessoais é a morte do outro, o luto, a linguagem torna-se ainda mais falha, incompleta, fragmentada. Se o retrato do eu na autoficção já era borrado e difuso, o retrato do luto o distorce ainda mais.

\title{
3 A representação da morte
}

De acordo com os estudos de Philippe Ariès, em $A$ história da morte no Ocidente (1974), a morte, antes representada como uma forma horrenda e feita 
para amedrontar os demais, hoje "basta apenas enunciá-la para provocar uma" tensão emocional incompatível com a regularidade da vida quotidiana” (ARIÈS, 2012, p. 224). 0 teórico acrescenta o modo como é preferível descrever o morrer, o que chama de acceptable style of dying (um "modo aceitável de morrer"): "aquele que evita as status forcing scenes, as cenas que arrancam o personagem de seu papel social, que o violam. Essas cenas são as crises de desespero dos doentes, seus gritos e lágrimas e, em geral, todas as manifestações demasiado exaltadas" (ARIÈS, 2012, p. 224-225). É preferível ser polido, contido, não apresentar o corpo morto em todos os seus detalhes. Quanto mais distante a morte, menos ela aflige aqueles que ficaram. 0 deixado, portanto, tem o dever de se conter, manter-se lúcido, a fim de não perturbar os demais.

Nos romances selecionados, a cena final de cada morto é descrita em detalhes, sem censuras ou polidez. É somente nas páginas quase finais que Knausgård se questiona sobre o momento da morte do pai, quando está na casa da avó, - onde o pai viveu durante seus últimos anos -, para organizar o velório: "Quando, por exemplo, chegou a ambulância? Veio logo? Ainda era possível salvar a vida dele quando a ambulância chegou, houve um atendimento de emergência? (...) 0 que ela disse quando eles entraram? Ele está lá dentro? E aí os acompanhou até a sala? (KNAUSGÅRD, 2015, p. 353). Como não estava presente no momento da morte, resta-lhe indagar sobre como as coisas aconteceram naquele dia. 0 confronto com o pai morto se dá quando ele e seu irmão vão encontrar o corpo já na capela: "As bochechas dele estavam avermelhadas, como que cheias de sangue. Deve ter ficado entranhado nos poros quando tentaram removê-lo. E o nariz estava quebrado" (KNAUSGÅRD, 2015, p. 382). Muitas páginas antes, o autor descreve o momento em que descobriu sobre o ocorrido através de uma ligação de seu irmão: "Três dias antes, por volta das duas da tarde, Yngve me telefonara. Logo percebi pelo seu tom de voz que havia acontecido alguma coisa, e a primeira coisa que pensei foi que meu pai tinha morrido" (KNAUSGÅRD, 2015, p. 211). A causa da morte é incerta: "Gunnar acabou de ligar. Vovó o encontrou numa poltrona hoje de manhã. Do que ele morreu? Não sei, provavelmente do coração" (KNAUSGÅRD, 2015, p. 212).

o que mais o aflige é a impossibilidade de sofrer. Seja consequência do choque, por ter sido uma morte inesperada, ou mesmo pela dificuldade em manter uma relação afetiva com o pai mesmo no momento da morte, o que parece é que o personagem sente-se culpado por não conseguir pensar no ocorrido como fato importante, que valesse "ocupar a sua consciência" (KNAUSGÅRD, 2015, p. 213). Ele começa a divagar sobre outros fatores, como, por exemplo, o dinheiro que a família recebeu pela venda da casa: "Será que ele tinha torrado aquilo tudo em tão pouco tempo? Meu pai morreu, e eu estou pensando no dinheiro que ele me deixou", o próprio personagem se justifica logo em seguida, "E daí? Eu penso no que penso, não posso evitar, certo?" (KNAUSGÅRD, 2015, p. 213-214). Para quem questiona? Para nós, leitores, em busca de uma aprovação, um método de justificar a culpa (ou a ausência dela)?

No livro do Tiago Ferro, a cena da morte da filha é construída a partir de vários fragmentos. Se Knausgård vai do enterro e retorna, nas páginas seguintes, ao momento do conhecimento da morte do pai através do telefone, em Ferro a morte aparece em tempos completamente desconexos e difusos durante a 
narrativa. Em "[madrugada de quarta para quinta-feira. pronome de tratamento: você. morte]", o protagonista descreve o momento em que a criança chega ao hospital:

Você liga para seu pai do corredor do Instituto da Criança. A sua filha está sendo atendida por uma equipe com mais de cinco pessoas, entre médicos e assistentes. Um deles fica exclusivamente aplicando massagem cardíaca. Um outro fala para ele como estão as medições de frequência do coração e dos pulmões. É a segunda vez que injetam adrenalina com uma seringa enorme no joelho direito dela. A seringa fica ali espetada. Quando o médico interrompe a massagem, o sinal sonoro de uma das máquinas se faz constante e a linha no monitor com altos e baixos fica reta como a do horizonte. Ele parece precisar de dois ou três segundos para processar essas mensagens e retomar o esforço que restabelece o som entrecortado por silêncios e o traçado irregular na cor verde que atravessa o fundo preto.

Pai, vem pra cá já. A Minha Filha tá morrendo. (FERRO, 2018, p. 54-55).

Visualizamos, com detalhes, os minutos finais até a conclusão já sabida pelo leitor: "Quarenta minutos depois eles desistem. A menina está morta" (FERRO, 2018, p. 56). Contrário ao personagem de Knausgård, que lida com a dificuldade de sentir alguma coisa diante da morte, Ferro descreve o momento da perda do Pai como a perda de si mesmo: "Ninguém sabe dizer em qual momento a equipe do hospital amputou os seus dois pés. Você não consegue se mover. (...) Os dois tocos de perna enterrados no chão emborrachado espalham uma gosma amarela por todo o corredor do hospital" (FERRO, 2018, p. 55). A metáfora da perda como uma amputação de seus membros relaciona a morte da filha com a perda de uma extensão de si. Para o protagonista, é impossível não buscar respostas: "Por que o coração parou? Qual a causa? Lázaro realmente ressuscitou? Por que Jesus perdeu tempo transformando água em vinho em vez de salvar uma criança?" (FERRO, 2018, p. 56). Perguntas que não levarão a nada e não realizarão o seu desejo de trazer sua filha de volta à vida.

Knausgård volta-se para o leitor em uma tentativa de redimir-se ao não se sentir culpado, Ferro volta o seu protagonista para dentro de si mesmo, a culpa tornou-se fato constituinte do personagem: "Você é um péssimo pai. Deixou a sua filha cair, bater a cabeça, se afogar, ser picada por uma cobra venenosa. Você deixou a sua filha sozinha em uma maca fria no Instituto da Criança coberta com um lençol de solteiro branco" (FERRO, 2018, p. 57). 0 que lhe resta após a morte? "Reescrever este livro pelo resto da minha vida" (FERRO, 2018, p. 25). Presos em um tempo cíclico, autor e personagem seguem, tal como Sísifo, no eterno processo da escrita do luto.

\section{Os "deixados"}

Philippe Ariès, ao falar do luto, ressalta a sua significação como "dor por excelência cuja manifestação era legítima e necessária" e complementa: "Muito antes de ter recebido um nome, a dor diante da morte de alguém próximo já era a 
expressão mais violenta dos sentimentos mais espontâneos" (ARIÈS, 2012, p. 227). A dor é parte integrante, tanto do conceito, quanto da própria palavra (em francês, luto é deuil, que retoma a palavra dor, douleur). Em espanhol, quando alguém morre, uma das formas de dizer "estou de luto", além de "estoy de luto", é se referir ao período como "estar de duelo". Duelo, que também significa luta, seja em espanhol ou em português. Estar de luto seria, nesse sentido, uma espécie de luta consigo mesmo, com a realidade da perda, com os outros e com a morte. E quando se luta com a consciência do morrer, não há vencedores.

A literatura apresenta a morte como a-gente 5 não gostaria de ver. Ivan Ilitch, o morto de Tolstói, encena a angústia do morrer. Shakespeare, muito antes, colocava Hamlet diante da caveira enquanto questionava se deveria continuar sendo ou não - e conclui a peça com um banho de sangue. Independente da época, do gênero, ou do estilo, a morte segue como tema recorrente na literatura.

Os deixados, também.

Em uma perspectiva histórica, Ariès ressalta o foco nos deixados como movimento típico dos tempos atuais: "Pouco a pouco, o interesse ou a compaixão, quando subsistiram, foram se deslocando do moribundo para a família e demais sobreviventes". Antes, honrávamos os mortos, hoje, "dirige-se mais aos sobreviventes, para edificá-los e consolá-los" (ARIÈS, 2012, p. 210). A identidade daquele que ficou é interpelada pela ausência do morto, torna-se um deixado, um sobrevivente, acima de tudo.

É justamente sobre a visão do deixado que Alamir Aquino Corrêa discorre em "O luto interminável: Barthes e a presença ausente" (2012). Barthes, um dia após a morte de sua mãe, inicia um diário composto por pequenos fragmentos que escreve durante seus dias de luto. Para Corrêa, ainda que haja palavra, há, fundamentalmente, um silêncio - uma impossibilidade em alcançar o morto: "Quer-se pedir perdão, algo impossível, inalcançável, impraticável, mas a única face que temos é a do morto em nós, como se fôssemos dele o seu espelho" (CORRÊA, 2012, p. 37). A presença da ausência complementa o deixado, que agora não existe mais somente como um único indivíduo, mas também pela ausência do outro que se foi. 0 eu é agora eu+morto, uma equação que não dá resultados conclusivos, porque o outro não existe mais para além de uma parte constituinte desse eu primeiro.

Nos dois romances selecionados para esta análise, temos acesso a narrativa de dois homens, enlutados, que escrevem sobre a perda de um ente familiar. Seria impossível não recorrer aos estudos da psicanálise para fundamentar uma discussão sobre o luto e suas consequências no indivíduo. 0 estudo clássico de Sigmund Freud, Luto e melancolia (1917), apresenta o luto não como um "estado patológico", já que não é necessário um tratamento médico, contudo, ressalta: "embora ele acarrete graves desvios da conduta normal da vida" (FREUD, 2013, p. 24). Sobre a não-patologização do luto, Ariès acrescenta: "A sociedade hoje recusa reconhecer no bereaved, no homem atingido pelo luto um doente que ela, pelo

\footnotetext{
${ }^{5}$ Referência ao conceito de Heidegger em Ser e Tempo (1927). É preferível ser a-gente do que serpara-a-morte. Ao ignorar o destino trágico dos seres, distanciando-se dos moribundos, afastando-se dos cemitérios, criando casas funerárias para que o morto esteja sempre longe, mais as pessoas (agente) acreditam estar "seguras" diante da morte.
} 
contrário, devesse socorrer". Estar de luto, nesse "duelo", não é como estar doente e necessitar de ajuda. 0 luto, conforme a metáfora que retoma Ariès de Geoffrey Gorer em um ensaio intitulado "Pornografia da morte", é como a masturbação: um ato solitário, feito às escondidas, mal visto pelos demais.

É no ritual funerário que o sobrevivente ganha, efetivamente, o título de enlutado. 0 velório é o momento de último contato (físico) entre os vivos e o(s) morto(s). Nos romances selecionados para a análise, ambos descrevem o último adeus durante o velório de seus entes. 0 fragmento "[sexta-feira: velório, sol a pino. versão I. menção honrosa para documentário de curta-metragem - júri oficial do festival É tudo verdade (It's All True)]", escrito em terceira pessoa, distancia o leitor da intimidade do Pai durante o velório de sua Filha:

Ele está dentro da sala do velório. É um amigo da família? Não, é o pai em pessoa. No caixão, aberto e branco, coberta de flores, é a filha morta em um vestido verde-claro com estampas florais. É uma roupa de festa. 0 que ele pensa? Ele consegue imaginar a apreensão das pessoas quando ele se aproxima da própria filha de oito anos? Alguns figurantes se perguntam por que ele entrou. Para que levar essa imagem estampada no cérebro e nas vísceras para sempre? Por uma fração de segundo ele pensa a mesma coisa. Mas nem se olhássemos nesse instante dentro do cérebro dele, poderíamos encontrar uma resposta minimamente satisfatória. As mãos dela, uma sobre a outra como em um retrato antigo, o formato de cada unha. 0 rosto com os olhos fechados. Ele toca as mãos dela. Há muita apreensão no set de filmagens agora. (FERRO, 2018, p. 68).

Escrito como uma cena gravada para um documentário, o narrador descreve os atos do Pai, e como se fosse o próprio leitor (ou espectador), antecipa as angústias diante dos seus movimentos: "Ele se inclina sobre o caixão. A filhinha dele está mesmo ali dentro deitada coberta com flores. E agora, meu Deus, o que ainda falta acontecer com esse pobre coitado?" (FERRO, 2018, p. 68). Nós, leitores, junto ao Pai e ao diretor/narrador, alimentamos a esperança vã de um milagre: "Como espectadores não podemos alterar o filme, o roteiro já foi decorado e a película está pronta. Mas na dobra do ator queremos acreditar que é possível interferir, agir, mudar as coisas. Bastaria bater palmas duas vezes e dizer pronto, agora acorda" (FERRO, 2018, p. 68-69). Mas o velório segue o seu rito sem alterações.

No romance de Knausgård, o velório é descrito de forma muito mais "burocrática" do que "íntima", como acontece em Ferro. Ao receber a ligação informando a morte do pai, o protagonista e o irmão decidem fazer o velório na casa da avó, último local que o pai morou. A casa, contudo, está um caos. Reflexo de uma vida alcoolizada tanto do pai quanto da avó, há lixo por todos os cantos, o quintal necessita de reparos - e a avó, que continua a viver nos cômodos, também exige cuidados. Em uma ligação para sua esposa, Tonje, o protagonista refere-se à casa como "uma casa de morte": "Estamos chafurdando na morte dele. Ele morreu na poltrona da sala ao lado, e ela ainda está aqui" (KNAUSGÅRD, 2015, p. 350). As páginas finais do romance refletem o conflito do personagem com o seu passado ao 
retornar para a casa que frequentava na infância. E é nesta mesma casa que ele dará adeus ao seu pai pela última vez, durante o velório:

Os olhos e a boca estavam fechados, a parte de cima do corpo vestia uma camisa branca, a de baixo calças pretas. A ideia de que pela primeira vez eu poderia observar livremente aquele rosto era quase insuportável. Parecia uma violação. Ao mesmo tempo, eu tinha que fazê-lo, um desejo insaciável que me forçava a encará-lo, aquele cadáver que até poucos dias antes fora meu pai. (KNAUSGÅRD, 2015, p. 208-209).

O simples fato de encarar o corpo do pai sem receios era por demais estranho e insuportável. Ao ver o homem de camisa branca e calças pretas deitado no meio da sala ocorre a transfiguração do que antes era a figura paterna para a figura de um morto. Como uma espécie de narrativa ao contrário, o luto de Knausgård inicia ao final do livro. É com o enterro do pai, e toda a experiência de quase "expurgo" ao arrumar a casa para o velório, que o luto passa a ser fato constituinte do protagonista, que já descreveu tanto de sua vida nas 200 páginas anteriores.

Para discutir o processo de luto, retomamos Sigmund Freud e suas proposições acerca do luto e da melancolia. De acordo com o psicanalista, o processo de luto, além de solitário, é também lento e exige do indivíduo um desligamento ao objeto perdido:

Creio que não é forçado descrevê-lo da seguinte maneira: a prova da realidade mostrou que o objeto amado já não existe mais e agora exige que toda a libido seja retirada de suas ligações com esse objeto. Contra isso se levanta uma compreensível oposição; em geral se observa que o homem não abandona de bom grado uma posição da libido, nem mesmo quando um substituto já se lhe acena. Essa oposição pode ser tão intensa que ocorre um afastamento da realidade e uma adesão ao objeto por meio de uma psicose alucinatória de desejo. 0 normal é que vença o respeito à realidade. Mas sua incumbência não pode ser imediatamente atendida. Ela será cumprida pouco a pouco com grande dispêndio de tempo e de energia de investimento, e enquanto isso a existência do objeto de investimento é psiquicamente prolongada. Uma a uma, as lembranças e expectativa pelas quais a libido se ligava ao objeto são focalizadas e superinvestidas e nelas se realiza o desligamento da libido. (FREUD, 2013, p. 25).

Em síntese: um objeto é perdido, a libido precisa desligar-se deste objeto, contudo, o indivíduo reluta. Ele cria para si uma "psicose alucinatória do desejo" em oposição à realidade da perda. Em um determinado momento, com o auxílio do tempo, a libido é desligada e o homem volta à realidade. Enquanto ainda lida (e luta) com o não-querer desligar-se do objeto perdido, o homem coexiste em diferentes tempos, como propõe Corrêa: "Está-se, pois, a lidar com o tempo que se foi (temps perdu), com o tempo futuro a ser encontrado (um temps retrouve). Essa 
passagem, a tarefa do luto, dolorida, é não pelo morto que já não mais é, mas por precisar o eu compreender o que foi e o que precisa ser" (CORRÊA, 2012, p. 38). Dividido entre o eu e o outro (morto), coexistindo entre o tempo passado e almejando o tempo futuro, o enlutado é sempre um entremeio de algo que ainda não fin(d)ou. Mas qual é o comportamento esperado para aquele que fica? Qual é a prescrição comportamental para o sobrevivente? 0 ritual da morte é comum, porém não há um manual de instruções para os que continuam.

De acordo com Philippe Ariès, "não convém mais anunciar seu próprio sofrimento e nem mesmo demonstrar o estar sentindo" (ARIÈS, 2012, p. 232-233). 0 teórico descreve a atitude esperada pelos parentes do morto: "o infeliz sobrevivente deve esconder seu sofrimento e renunciar a recolher-se numa solidão que o trairia, continuando sem descanso sua vida de relações sociais, de trabalho e de lazeres" (ARIÈS, 2012, p. 241). Vejamos como cada um dos enlutados dos romances reproduzem, ou não, o que pressupõe Ariès. Karl, protagonista de Knausgård, descreve a sua reação no dia seguinte ao enterro do pai a partir de uma metáfora:

\begin{abstract}
Nenhum vestígio das fortes emoções vividas na véspera, eu apenas parecia cansado. Então, de volta aonde parei. Pois a véspera tampouco deixara vestígios internos. Sentimentos são como água, sempre adquirem a forma do meio que os circunda. Nem mesmo o pior luto deixa vestígios, se é esmagador e dura muito tempo, não é porque os sentimentos congelaram, isso eles não conseguem fazer, mas porque não se mexem, como a água estagnada de um charco. (KNAUSGÅRD, 2015, p. 239).
\end{abstract}

No início, atordoado pela perda, a água se move com rapidez, consequentemente seus sentimentos estão também muito mais evidentes. Seguindo com a metáfora: seus sentimentos estão à margem, prestes a desaguar. Contudo, com o passar do tempo, no caso o dia seguinte, tudo se acalma. 0 mar retorna ao seu habitual ir e vir. Ele sente a perda, porém a água não se move mais. É como o viver entre diferentes tempos (passado e futuro, conforme Corrêa), de calmaria e agitação.

O Pai, personagem do romance de Tiago Ferro, frequentemente questiona a si mesmo como agir após a morte da filha:

Qualquer gesto meu é superinterpretado num nível de paranoia e exegese. Quando eu estou apenas calado, estou deprimido. Quando eu converso alegremente, estou tentando apagar o passado. Se eu tenho uma ereção, é uma compensação típica do luto. Se eu como pouco, é bom ir ao médico. Se eu como muito, é bom ir ao médico. Se eu cortar os pulsos, ou entrar debaixo de um ônibus em movimento, ou pular do topo do Empire State Building, estava na cara que algo assim ia acontecer. Também. (FERRO, 2018, p. 49).

0 personagem faz uma lista com as mensagens de apoio recebidas entre 2016 e 2017: "Conte comigo. Um imenso abraço. Estou sem palavras. Todo amor para você. Meu Deus! Me diga se posso ajudar em algo. Estarei sempre ao seu lado. 
Fé, muita fé. Foi antinatural. Sinto muito. Muito. Muito. Sinto muitíssimo", e entre elas não deixa de incluir prováveis pensamentos íntimos de si mesmo com relação a morte da filha: "Você se fodeu" (FERRO, 2018, p. 90-91).

Por mais diferente que seja o modo com que os dois romances tratam o comportamento do enlutado, é semelhante o fato de ambos apresentarem uma consideração sobre o agir após a morte de alguém. A construção da narrativa de Knausgård, por exemplo, entrecortada por memórias da infância, interpela a representação do luto com as lembranças do pai ainda vivo (e, principalmente, da sua indiferença para com o filho). Tiago Ferro fragmenta seu relato ao máximo, introduzindo diversas cenas, quase flashs, de momentos diversos enquanto discute sobre sua perda.

A culpa é o elemento comum entre os protagonistas. Enquanto Ferro ressalta a identidade de ausência do seu protagonista, é um pai sem filha; Knausgård sente-se dividido por ter tido uma relação conturbada com o pai durante toda sua vida e agora ter que lidar com a sua morte. Ainda que Karl não exponha, como faz o Pai, sua intimidade enlutada, ele é, também, resultado da morte. Toda a sua narrativa, assim como a de Ferro, partem dela. Fadados a lidar com a perda, de si e do outro, eles precisam expurgar, de alguma forma, a dor. E a escrita surge como a possibilidade mais próxima.

\section{$5 \quad$ A escrita íntima do luto}

Em uma análise rápida dos títulos dos romances selecionados, notamos que a morte atua subjetivando ou adjetivando a figura paterna. Em Knausgård, é o substantivo; em Ferro, o adjetivo. É a partir do sentimento do luto, ao ter que lidar com a perda, que nasce a narrativa. Nesse momento, unimos a teoria do luto com as teorias da autobiografia e autoficção. Escrever sobre a perda é um mergulho na morte, é expor a ferida como não deve ser feito, é estar preso no ciclo vicioso do luto em busca de tentativas de trazer de volta o que não tem retorno.

Proíbem que se fale da morte, contudo o tema atrai. A metáfora do luto como masturbação que retoma Ariès, cabe aqui, mais uma vez. Como um texto erótico a ser lido às escondidas, a morte assombra e atrai os leitores: "Isso sugere que o público dos leitores de jornais começa a se interessar pela morte, de início talvez como uma coisa proibida e um tanto obscena" (ARIÈS, 2012, p. 214-215). E o tema continua a ser, como no Romantismo, uma possibilidade de infinitas histórias.

Mas falávamos de textos autobiográficos e da morte, e é nesse local em que se encontram Ferro e Knausgård. Assombrados pela perda, a morte é a força destrutiva e criativa que os leva a escrever. Durante vários momentos da narrativa, Ferro insere entre colchetes a palavra "lista", e insere elementos metaficcionais sobre seu livro enquanto o escreve. Por exemplo: "De títulos para este livro" (FERRO, 2018, p. 18-19); “Do que eu ainda vou fazer neste livro" (FERRO, 2018, p. 25-26), ou "Do que não vai dar para fazer neste livro", a lista de um único tópico: "Trazer a Minha Filha de volta à vida" (FERRO, 2018, p. 35). Knausgård deixa explícito, nas páginas finais, que o seu livro era dedicado ao seu pai: "Tinha escrito o livro para papai. Eu não sabia, mas era isso. Tinha escrito o livro para ele" (KNAUSGÅRD, 2015, p. 395). 
Em suma, escrevem porque sofrem, e sofrem a cada vez que escrevem. Em termos psicanalíticos, talvez ainda estejam presos à "psicose alucinatória do desejo", e utilizem da escrita como meio de alcançar o objeto já perdido. A escrita é a ponte, também fantasiosa, que os liga, mais uma vez, ao morto. Contudo, a cada parágrafo é preciso ir mais além. A tragédia é o alimento da letra seguinte, a escrita é o exorcismo de algo que é sempre lembrado. A relação entre o eu vivo que escreve para um morto que não ouve é analisada por Alamir Corrêa, que ressalta: "a construção do monumento não interessa ao morto, sim aos vivos" (CORRÊA, 2012, p. 33), pois são eles, transmutados pela perda, que sentem a urgência de expurgar (ou apenas lembrar) os que se foram.

Retomando a psicanálise, Julia Kristeva, com base nos estudos de Freud, descreve em Sol negro: depressão e melancolia (1987) a figura do melancólico. Ainda que neguemos a classificação clínica para os personagens (ou mesmo dos próprios autores), o termo nos serve quando analisamos o luto (ou mesmo a sensação de melancolia) como motivação para a escrita. No caso, Kristeva menciona a "escrita do melancólico". De acordo com a teórica, a palavra do melancólico (ou deprimido) é sempre "repetitiva e monótona. Na impossibilidade de encadear, a frase interrompe, esgota-se, para" (KRISTEVA, 1989, p. 39). Considerando as duas narrativas, a fragmentação é um ponto em comum, ainda que apresentadas de formas diferentes. Knausgård reconta a morte do pai intercalando memórias da infância, Tiago Ferro divide seu texto em pequenos fragmentos separados por entradas entre colchetes. Por mais "recortadas" que sejam as narrativas, há sempre um mesmo tema que se repete: o luto. Isso porque, como continua Kristeva: "Um ritmo repetitivo, uma melodia monótona vem dominar as sequências lógicas quebradas e transformá-las em litanias recorrentes, enervantes" (KRISTEVA, 1989, p. 39).

Ainda que se diga sempre do outro, daquele que se foi, é somente a voz do autor-protagonista-deixado que se ouve. 0 resto é sempre silêncio: "Estar diante do morto é obrigar-se ao silêncio, pela impossibilidade do diálogo, reconhecê-lo obriga também a anular-se, o morto em nós, para que ele fale" (CORRÊA, 2012, p. 36). Novamente, o dilema: um diálogo de surdos, o monólogo da ausência. A força destrutiva, a experiência do luto, se liga com a força criativa que urge em um eu que se tornou resultado da soma (e sombra) da morte.

Imersos na narrativa do luto, presos em tentativas vãs de recontar a perda, as barreiras se mesclam e o personagem (d)escreve também sobre o próprio ato de escrever. Ferro chega ainda a adicionar opiniões de possíveis revisores/editores sobre os primeiros manuscritos: "[whatsapp] Querido, o pessoal da editora adorou a amostra que você mandou. Mas eles querem mais. Mais verdade. Mais benzina. Mais sangue. Eles querem suas vísceras. Beijinho" (FERRO, 2018, p. 90). Karl Ove Knausgård, um autor com alguns romances publicados e um certo prestígio na Noruega, retrata a luta diária com a escrita íntima: "Por muitos anos eu tentara escrever sobre meu pai, mas jamais conseguira, decerto por que o tema era próximo demais da minha vida, e portanto nada fácil de transpor para outra forma, o que, naturalmente, é um pré-requisito da literatura" (KNAUSGÅRD, 2015, p. 182). É por isso que, ao se dar conta de ter escrito algo tão íntimo, ele chora: 
A primeira vez que me dei conta de que o que eu escrevia tinha algum valor, que não era apenas eu querendo ser alguém, ou fingindo ser alguém, foi quando escrevi uma passagem sobre papai e comecei a chorar enquanto escrevia. Jamais acontecera aquilo, nem nada parecido. Escrevi sobre papai e as lágrimas escorreram pelo meu rosto, eu mal conseguia enxergar o teclado ou a tela, apenas seguia digitando. Não sabia daquele sofrimento que acabava de ser liberado dentro de mim naquele instante, não tinha ideia de que ele existia. Meu pai era um idiota, eu não queria nada com ele, e não me custava nada ficar distante. A questão não era ficar distante dele, a questão era que ele não existia, nada que dizia respeito a ele me afetava. Era assim que tinha sido, mas então me pus a escrever e as lágrimas jorraram. (KNAUSGÅRD, 2015, p. 395).

No momento em que deixa de escrever uma ficção distanciada e volta para si mesmo, ele chora. 0 sentimento o invade porque é mais fácil recriar-se em outro, distanciado, do que tentar retratar algo tão pessoal quanto o luto. A escrita íntima do luto vai além do escrever sobre si, borrar o eu ou alterar alguns fatos. Assombrados pela perda, escrever é o exercício mais difícil que paira entre a lembrança e o esquecimento - a morte, companheira, é quem revisa e dita aos seus enlutados a frase seguinte.

\section{Pai sem filha, filho sem pai: conclusão}

Em um percurso gradativo, partimos dos escritos autobiográficos, da representação da morte e da perda, para encontrarmos, enfim, a escrita íntima do luto. Knausgård e Ferro escrevem a partir da perspectiva de um "eu-e-o-outro", conforme discute Corrêa: "A morte transforme o eu, que se vê diante daquele que se foi; se por um lado, há o surgimento do eu-e-o-outro (especialmente pela memória e pelo dever ético), surge outro eu, que se descobre e se postula diferente nessa descoberta" (CORRÊA, 2012, p. 44). A identidade passa a ser eu+perda, uma soma que resulta sempre em ausência.

Ao escolherem escrever sobre perdas particulares, de "personagens reais" de suas vidas, a escrita caminha em direção a uma espécie de "expurgo". Roland Barthes, por exemplo, ao manter um diário de fragmentos após a morte da mãe, transforma o processo de luto em uma "autoanálise": "A palavra é a construção controlada da emoção, realizando isto (no sentido de ter existência concreta) por meio de um ato cerimonial, ordenando-a como se pudesse, através dela (da palavra organizada), efetivar a liturgia ética necessária e pretendida enquanto dever moral" (CORRÊA, 2012, p. 54). A escrita íntima do luto parte da experiência real e realiza-se na palavra. É o encontro final de um processo eterno: a perda não finda no ponto final, no enterro, no velório. Nascidas pela, e através, da perda, as narrativas mesclam realidade e ficção, morte e renascimento, memória e esquecimento. 


\section{Referências}

ARFUCH, Leonor. O espaço autobiográfico: dilemas da subjetividade contemporânea. Tradução de Paloma Vital. Rio de Janeiro: EdUERJ, 2010.

ARIÈS, Philippe. História da morte no Ocidente: da Idade Média aos nossos dias. Tradução de Priscila Viana de Siqueira. Ed. especial. Rio de Janeiro: Nova Fronteira, 2012.

CAVIGLIOLI, David. Karl Ove Knausgaard: "J'ai créé un montre que je ne contrôle plus". Bibliobs, 2014. Disponível em: https://bibliobs.nouvelobs.com/rentree-litteraire2014/20140919.0BS9702/karl-ove-knausgaard-j-ai-cree-un-monstre-que-je-ne-controleplus.html. Acesso em: 20 jul. 2020.

CORRÊA, Alamir Aquino. 0 luto interminável: Barthes e a presença ausente. Revista da Anpoll, Florianópolis, v. 1, n. 33, p. 27-56, mar./maio 2012.

DOUBROVSKY, Serge. 0 último eu. In: NORONHA, Jovita Maria Gerheim. Ensaios sobre a autoficção. Tradução de Jovita Maria Gerheim Noronha e Maria Inês Coimbra Guedes. Belo Horizonte: Editora UFMG, 2014. p. 111-126.

FERRO, Tiago. O pai da menina morta. São Paulo: Todavia, 2018.

FREUD, Sigmund. Luto e melancolia. Tradução, introdução e notas de Marilene Carone. Textos: Maria Rita Kehl, Modesto Carone e Urania Tourinho Peres. São Paulo: Cosac Naify, 2013.

KNAUSGÅRD, Karl Ove. A morte do pai: minha luta 1. 2. ed. Tradução de Leonardo Pinto Silva. São Paulo: Companhia das Letras, 2015.

KRISTEVA, Julia. Sol negro: depressão e melancolia. Tradução de Carlota Gomes. Rio de Janeiro: Rocco, 1989.

LEJEUNE, Philippe. O pacto autobiográfico: de Rousseau à Internet. Organização de Jovita Maria Gerheim Noronha. Tradução de Jovita Maria Gerheim Noronha, Maria Inês Coimbra Guedes. 2. ed. Belo Horizonte, Editora UFMG, 2014.

O PAI DA MENINA MORTA, por Tiago Ferro (entrevista), 2019. Publicado pelo canal Litera Tamy. Disponível em: https://www.youtube.com/watch?v=CwhqlLv0ZFI. Acesso em: 30 jul. 2020.

PERRONE-MOISÉS, Leyla. Mutações da literatura do século XXI. São Paulo: Companhia das Letras, 2016.

Para citar este artigo

AMARAL, Lara Luiza Oliveira; LUDWIG, Eduardo Bertoli. Filho sem pai, pai sem filho: a escrita íntima do luto. Miguilim - Revista Eletrônica do Netlli, Crato, v. 10, n. 1, p. 415-430, jan.-abr. 2021. 
Lara Luiza Oliveira Amaral é doutoranda (e bolsista CAPES) em Teoria e História Literária pela Universidade Estadual de Campinas (UNICAMP), mestra em Estudos Literários pela Universidade Estadual de Maringá (UEM), especialista em Estudos Literários pela Universidade Estadual do Paraná (UNESPAR - campus de Campo Mourão) e graduada em Letras Inglês e Português pela mesma universidade. ORCID: https://orcid.org/0000-0002-6870-3576.

Eduardo Bertoli Ludwig é graduado em Letras - Português/Inglês na Universidade Estadual do Paraná (UNESPAR) - campus de Campo Mourão. ORCID: https://orcid.org/0000-0001-7745-2724. 